\title{
THE EFFECT OF SERVICE QUALITY AND BRAND IMAGE ON REPURGHASE INTENTION WITH BRAND TRUST AS MEDIATING VARIABLE BY THE GENERATION 2 OF E- WALLET CONSUMERS IN JAKARTA
}

\section{Dwi Asri Ningrum ${ }^{1 *}$}

Mohamad Rizan ${ }^{2}$

Agung Kresnamurti Rivai $\mathbf{P}^{3}$

1,2,3 Faculty of Economics, Universitas Negeri Jakarta, Indonesia

e-mail: dwiasriningrum8@gmail.com¹, mohamadrizan72@unj.ac.id², ak.prabu9999@gmail.com³

*Correspondence: dwiasriningrum8@gmail.com ${ }^{1}$

Submitted: 23 October 2021, Revised: 10 November 2021, Accepted: 14 November 2021

Abstract. The purpose of this study was to examine the effect of service quality (X1) and brand image $(\mathrm{X} 2)$ on repurchase intention $(\mathrm{Z})$ through brand trust $(\mathrm{Y} 1)$ as an intervening variable on generation $\mathrm{Z}$ e-wallet consumers in Jakarta. Data collection methods use questionnaire-style tools to conduct surveys. The sample of this study is 300 respondents of Gen $Z$ consumers aged 17-26 in Jakarta who have made at least five transactions or payments through the ewallet application in the last month. Data analysis technology uses SPSS 25 version and SEM from LISREL 8.8 version statistical package to process and analyze research data. The results show that: 1) service quality has a significant effect on brand trust for generation $Z$ e-wallet consumers in Jakarta, 2) brand image has a significant effect on brand trust on generation $\mathrm{Z}$ e-wallet consumers in Jakarta, 3) brand trust has a significant effect on repurchase intention of generation $Z$ e-wallet consumers in Jakarta, 4) service quality has a significant effect on repurchase intention of generation $Z$ e-wallet consumers in Jakarta, 5) brand image has a significant effect on repurchase intention of generation $Z$ e-wallet consumers in Jakarta, 6) service quality has a significant effect on repurchase intention through brand trust as an intervening on generation $\mathrm{Z}$ e-wallet consumers in Jakarta, 7) brand image has a significant effect on repurchase intention through brand trust as an intervening on generation $Z$ e-wallet consumers in Jakarta. This research can contribute new information and knowledge about ewallet in developing countries, especially Indonesia.

Keywords: service quality; brand image; brand trust; repurchase intention; generation z; ewallet consumers. 


\section{INTRODUCTION}

In the Industrial Revolution 4.0 period, there was rapid development in digital technology. The internet can reach a broader target market. The Southeast Asian region, including Indonesia, ranks third for the highest internet usage growth in the world, which is $9.6 \%$ in one year Kemp, 2021.

Fintech is a digital transformation introducing new concepts in the financial services industry Kaushal \& Ghosh, (2016). Intense pressure from Gen $Z$ is the main driving force for Fintech providers \& banks to digitize monetary services so that they are available through digital channels, especially smartphones Meola, (2017). Fintech transactions in Indonesia in 2017 reached US\$18.65\%. Around 14 percent or US\$ 280 billion of this value will be controlled by payment Fintech.

E-commerce has changed the way people transact using electronic money payments, and one of them is an e-wallet. According to the Times (2021), an e-wallet is an electronic wallet that is practically used for online payments and financial transactions using a smartphone. Based on data from Capgemini, (2021). Global ecommerce continues to grow at 19\% CAGR (2017 - 2023), reaching $\$ 6.5$ trillion. Ewallet is the preferred e-commerce payment method with a $52 \%$ market share in 2023.

Cashless payments through the digital system refer to alternative prices, primarily to suppress the spread of COVID-19. Based on research results from Capgemini \& BNP Paribas, the number of e-wallet users will increase from 2.3 billion in 2019 to nearly 4 billion in 2024 Capgemini, (2021).

There are many features and advantages in e-wallet that make it easier for consumers' financial transactions. Transaction speed and the convenience of paying anytime and anywhere are the top two factors that motivate users to make payments via e-wallet. However, from the growth opportunities of e-wallet globally, several problems hinder the use of e-wallet. Where cash still dominates. The information shows that $64 \%$ of the populace matured 15 years over still don't have bank accounts, and just around 4\% of the public has credit cards KPMG, (2017).

No. 2 after the virtual card globally. Based on data from The Asian Banker, Indonesia has 270 million people, and more than $50 \%$ still do not have a bank account due to geographical barriers. The low development of e-wallets in Indonesia is the element behind one of the authors' research on e-wallets. On the other hand, the Capgemini \& BNP Paribas survey found that over the next two to three years, ewallet will become a digital payment initiative Capgemini, (2021). An overview by the Indonesian Internet Service Providers Association (APJII) uncovered that $56 \%$ or 95.8 million of Indonesia's Internet users never shopped online. At the same time, there are approximately $6,000,000$ online merchants in Indonesia.

From the problems above, Indonesia has more than $60 \%$ of the population equipped with smartphones Banker, (2021). The increasing number of cellular technology and the penetration of internet users can affect the expansion of e-wallet Capgemini, (2021).

Current research is focused on 
342 The Effect of Service Quality and Brand Image on Repurchase Intention With Brand Trust as Mediating Variable by The Generation Z of E-Wallet Consumers in Jakarta

Generation Z, which has the most interaction with technology today. Gen $Z$ is the generation born between 1995 and 2009. Jakarta is currently one of the major emerging markets, which forms the basis for the future growth of Indonesia's financial technology and the growing trend of electronic transactions already visible in Jakarta, making it an exciting area to be researched Smartcity Jakarta, (2019).

In Indonesia, as indicated by a new report by Iprice, GoPay, OVO, DANA, LinkAja are the best four e-wallets with the most significant number of month-tomonth active users and the most downloads from the second quarter of 2019 to the second quarter of 2020.

Saleem et al. (2017) identify in Pakistan's aviation industry, service quality, and trust affect repurchase intentions are straightforwardly and positively correlated through customer satisfaction. Service quality straightforwardly and positively correlated with repurchasing intentions through brand image. Sullivan \& Kim (2018) state that repurchase intention can be increased by the brand trust that consumers get from the service quality of the e-wallet and the brand image of the ewallet itself. Brand Image simultaneously has a positive and significant impact on purchasing decisions, as stated by Juwariyah, (2021).

This research is to see more about how the Indonesian people, especially the people of Jakarta, recognize e-wallet. Likewise, this study also aims to decide the elements that impact buyers' taking on ewallet, regardless of whether service quality and brand image significantly affect brand trust and repurchase intention of e-wallet.
Whether the brand trust significantly affects repurchase intention of e-wallet by Generation Z in Jakarta. The choice to focus just on this age is relied upon to comprehend the mental conduct that underlies Generation $Z$ in utilizing an ewallet.

\section{Service Quality}

As indicated by Al-Tit (2015), service quality is an assessment by comparing consumer expectations with the perceived service experience of consumers. Chang et al., (2020) conceptualize service quality with two elements, namely "what" and "how". The "what" element describes the service output, i.e., what the company/service provider delivered. The "how" element details the service delivery process, i.e., how it is shown. According to Pakurár et al., (2019), there are several things related to dimensions of service quality or also called SERVQUAL, that are tangible, reliable, responsive, assurance, and empathy. In the research of Al-dweeri et al. (2017), service quality has a positive and significant impact on brand trust. Improving service quality in dealing with potential customers can increase brand trust because it is one of the essential elements of brand trust in internet shopping. According to Lasmy et al. (2019), the researchers observed that service quality significantly affects repurchase intention on Grab and GoJek as online transportation.

Hypothesis 1: Service quality significantly affects brand trust in generation $\mathrm{Z}$ e-wallet consumers in Jakarta.

Hypothesis 4: Service quality significantly affects the repurchase intention of generation Z e-wallet consumers in Jakarta. 


\section{Brand Image}

In Kotler et al.'s (2016) study, brand image is a buyer's view of a brand, as reflected in the brand associations in customers' recollections. Srivastava \& Sharma (2013) identify the brand image as an essential concept to prove the reputation and credibility of the company in customer satisfaction with the products or services used. A few dimensions of the brand image shown by lšoraite (2018) are 1. brand identity, brand character, brand association, brand attitude, customer benefits. In the study of Han et al. (2019), it is observed that the hypothesis of the brand image significantly affects brand trust in South Korean airlines. According to Iskandar \& Berlianto, (2018), exploration expressed that brand image significantly affects repurchase intention. For specific brands, customers foster intellectual and emotional reactions, then, at that point, over and over purchase particular brands.

Hypothesis 2: Brand image significantly affects brand trust on generation Z e-wallet consumers in Jakarta.

Hypothesis 5: Brand image significantly affects the repurchase intention of generation Z e-wallet consumers in Jakarta.

\section{Brand Trust}

Brand trust is belief in product/service performance/brand safety, as consumer expectations and beliefs that the brand will continue to provide its best functions and performance for the benefit of consumers (Han et al., 2019). In marketing relation, brand trust is the readiness of buyers to be associated with the next transaction in the future, which reflects trust in the seller's value-based conduct, in this way prompting repurchase intention Javed \& Wu, (2020). According to Kim et al., (2003), brand trust has several dimensions: ability, benevolence, and integrity. In Horng (2020) research, brand trust in products will significantly affect repurchase intention for products traded on any website.

Hypothesis 3: Brand trust significantly affects the repurchase intention of generation Z e-wallet consumers in Jakarta.

\section{Repurchase Intention}

Repurchase intention is the subjective probability that experienced customers will keep purchasing items/services/products from a similar company Trivedi \& Yadav, (2020). Repurchase intention is an activity where service users or customers positively respond to their first purchase so that they experience repeat purchases in the future Lasmy et al., (2019). According to Kotler et al. (2016), the dimensions of repurchase intention, namely transactional intentions, referential intentions, preferential intentions, and exploratory intentions. In $\underline{\mathrm{Q}}$ \& Yao (2020) research, brand trust intervenes in connecting multi-channel integration service quality with repurchase intention. In the exploration of Benhardy et al. (2020), brand trust positively moderates the connection of brand image with repurchase expectation for BINUS Online Learning.

Hypothesis 6: Service quality significantly affects repurchase intention through brand trust as an intervening on generation $\mathrm{Z}$ ewallet consumers in Jakarta.

Hypothesis 7: Brand image significantly affects repurchase intention through brand trust as an intervening on generation $\mathrm{Z}$ e- 
344 | The Effect of Service Quality and Brand Image on Repurchase Intention With Brand Trust as Mediating Variable by The Generation Z of E-Wallet Consumers in Jakarta

wallet consumers in Jakarta.

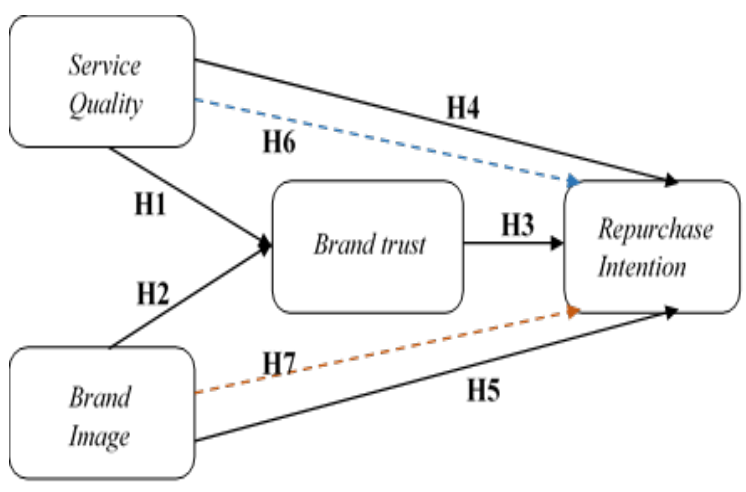

Figura. 1 Research Model

Source: Data processed by the author (2021)

\section{METHODS}

This research utilizes a quantitative approach. The data collection method in this study is a survey method. According to Hardani et al. (2020), the survey research method uses a questionnaire as a research instrument.

\section{Respondent}

The population taken in this study are Generation Z consumers in the Jakarta area who have made transactions or payments through the e-wallet application. In this study, the sampling technique utilized is non-probability sampling that uses the method of purposive sampling, which this study has criteria. The respondents sought were consumers of Generation Z aged 1726 years who live in the Jakarta area and have made transactions or payments through e-wallet applications at least five times in the last month. In this study, 300 respondents participated online using Google Form.

\section{Measurement}

Data retrieval was conducted using questionnaires and using a Likert measuring scale. There are five-point rating scales in this study, so respondents are more facilitated because the categories have a precise order, ranging from "strongly disagree" to "strongly agree" Malhotra \& Dash, 2010. The questionnaire is divided into several sections. The first part contains questions about the respondent's identity, such as age, occupation, income, domicile. The following section contains statements of several indicators that are adjusted to the variables to be studied. It adapted the information regarding service quality from Ahmad \& Zhang (2020), Sultan \& Wong (2019), and Saleem et al. (2017). For the brand image statement based on the literature from Benhardy et al. (2020), Išoraite (2018), and Zhang (2015). For the brand trust, which it adopted from Qalati et al. (2021), Benhardy et al. (2020), and Han et al. (2019), and the repurchase intention statement adapted from Trivedi \& Yadav (2020), Lasmy et al. (2019), Saleem et al. (2017), and Tandon et al. (2017).

\section{Analysis}

This research uses SPSS software version 25 and LISREL version 8.8 to analyze the data. This research uses the SEM (Structural Equation Modelling). The model of data analyzed in this research includes descriptive analysis, validity test using the Pearson test that, when the calculated $r$ value is greater than the $r$ table, the Pearson value is considered valid. But on the other hand, when the computed $r$ is smaller than the table r-value, the calculated $r$-value is invalid. When testing 
reliability, the Cronbach Alpha method is used to measure reliability. Its range is 0 to 1 , and the value is 0.6 to 0.7 , which is considered the acceptable minimum. If the Cronbach Alpha value is 0.7 and can be reduced to 0.6 in the exploratory research, it can declare the variable reliable Hair et al., (2010). According to Malhotra \& Dash (2010), several models are divided into three parts: the absolute fit measure, the suitable incremental standard, and the Parsimon appropriate action. The full SEM model in this study aims to analyze the four variables to know the influence and relationship between variables. It must first test the complete model for the goodness of fit. The service quality, brand image, and brand trust are variables measured by five indicators. Six indicators measure the variable of repurchase intention. Calculating direct and indirect effects using SEM is to compare the coefficients of direct and indirect influence, then check whether the hypothesis is significant or not. It can see that the mediating role of the variable is more important or the direct relationship is more excellent. In this research, the standardized total effect value states the hypothesis result of testing from the connection between the variables. The development of the data analysis will determine the size of the impact and the relationship between the variables. The test criteria look at the $t$-values between variables and then compare them with their critical values (t-table). With this, the relationship with $t$-values $>1.96$ can be declared significant. 
346 | The Effect of Service Quality and Brand Image on Repurchase Intention With Brand Trust as Mediating Variable by The Generation Z of E-Wallet Consumers in Jakarta

\section{RESULTS AND DISCUSSINN}

Table 1. Descriptive Analysis Table Service Quality

\begin{tabular}{|c|c|c|c|c|c|c|}
\hline Item & Statement & SD & D & $\mathbf{N}$ & A & SA \\
\hline \multirow[t]{2}{*}{ SQ1 } & \multirow{2}{*}{$\begin{array}{l}\text { The completeness of the features in } \\
\text { the e-wallet application makes it } \\
\text { easier for me to make financial } \\
\text { transactions online. }\end{array}$} & 2 & 3 & 56 & 132 & 107 \\
\hline & & $0.67 \%$ & $1.00 \%$ & $18.67 \%$ & $44.00 \%$ & $35.67 \%$ \\
\hline \multirow[t]{2}{*}{ SQ2 } & \multirow{2}{*}{$\begin{array}{l}\text { The admin fee for each transaction } \\
\text { paid on the e-wallet application is } \\
\text { cheaper than other digital payment } \\
\text { applications. }\end{array}$} & 2 & 7 & 66 & 143 & 82 \\
\hline & & $0.67 \%$ & $2.33 \%$ & $22.00 \%$ & $47.67 \%$ & $27.33 \%$ \\
\hline \multirow[t]{2}{*}{ SQ3 } & \multirow{2}{*}{$\begin{array}{l}\text { The e-wallet application speeds up } \\
\text { or improves my time efficiency when } \\
\text { transacting financially online. }\end{array}$} & 1 & 5 & 52 & 128 & 114 \\
\hline & & $0.33 \%$ & $1.67 \%$ & $17.33 \%$ & $42.67 \%$ & $38.00 \%$ \\
\hline \multirow[t]{2}{*}{ SQ4 } & \multirow{2}{*}{$\begin{array}{l}\text { I am satisfied with the experience of } \\
\text { using the e-wallet application. }\end{array}$} & 1 & 4 & 55 & 139 & 101 \\
\hline & & $0.33 \%$ & $1.33 \%$ & $18.33 \%$ & $46.33 \%$ & $33.67 \%$ \\
\hline \multirow[t]{2}{*}{ SQ5 } & \multirow{2}{*}{$\begin{array}{l}\text { The services provided by the e-wallet } \\
\text { application match or are better than } \\
\text { what I expected }\end{array}$} & 2 & 5 & 63 & 142 & 88 \\
\hline & & $0.67 \%$ & $1.67 \%$ & $21.00 \%$ & $47.33 \%$ & $29.33 \%$ \\
\hline & Total Frequency & 8 & 24 & 292 & 684 & 492 \\
\hline \multirow{2}{*}{\multicolumn{2}{|c|}{ Percentage }} & 0.53 & 1.60 & 19.47 & 45.60 & 32.80 \\
\hline & & $\%$ & $\%$ & $\%$ & $\%$ & $\%$ \\
\hline
\end{tabular}

Source: Data processed by the author (2021)

Table 2. Descriptive Analysis Table Brand Image

\begin{tabular}{|c|c|c|c|c|c|c|}
\hline Item & Statement & SD & D & $\mathbf{N}$ & A & SA \\
\hline \multirow[t]{2}{*}{ BI1 } & \multirow{2}{*}{$\begin{array}{l}\text { The e-wallet companies have a good } \\
\text { and credible reputation. }\end{array}$} & 1 & 3 & 75 & 150 & 71 \\
\hline & & $0.33 \%$ & $1.00 \%$ & $25.00 \%$ & $50.00 \%$ & $23.67 \%$ \\
\hline \multirow[t]{2}{*}{$\mathrm{BI2}$} & \multirow{2}{*}{$\begin{array}{l}\text { The e-wallet application has a } \\
\text { distinctive logo so that it is easy for } \\
\text { me to remember. }\end{array}$} & 3 & 3 & 61 & 133 & 100 \\
\hline & & $1.00 \%$ & $1.00 \%$ & $20.33 \%$ & $44.33 \%$ & $33.33 \%$ \\
\hline \multirow[t]{2}{*}{ BI3 } & \multirow{2}{*}{$\begin{array}{l}\text { In my opinion, e-wallet applications } \\
\text { offer more advantages than other } \\
\text { digital payment applications. }\end{array}$} & 1 & 5 & 68 & 148 & 78 \\
\hline & & $0.33 \%$ & $1.67 \%$ & $22.67 \%$ & $49.33 \%$ & $26.00 \%$ \\
\hline \multirow[t]{2}{*}{ BI4 } & \multirow{2}{*}{$\begin{array}{l}\text { Technological innovations and } \\
\text { features in e-wallet applications are } \\
\text { very modern. }\end{array}$} & 2 & 2 & 61 & 138 & 97 \\
\hline & & $0.67 \%$ & $0.67 \%$ & $20.33 \%$ & $46.00 \%$ & $32.33 \%$ \\
\hline \multirow[t]{2}{*}{ BI5 } & \multirow{2}{*}{$\begin{array}{l}\text { The e-wallet application is always } \\
\text { remembered as a digital payment } \\
\text { transaction application that is more }\end{array}$} & 1 & 4 & 59 & 140 & 96 \\
\hline & & $0.33 \%$ & $1.33 \%$ & $19.67 \%$ & $46.67 \%$ & $32.00 \%$ \\
\hline
\end{tabular}


practical than other digital payment

applications.

\begin{tabular}{cccccc}
\hline Total Frequency & 8 & 17 & 324 & 709 & 442 \\
\hline Percentage & $0.53 \%$ & $1.13 \%$ & $21.60 \%$ & $47.27 \%$ & $29.47 \%$ \\
\hline
\end{tabular}

Source: Data processed by the author (2021)

Table 3. Descriptive Analysis Table Brand Trust

\begin{tabular}{|c|c|c|c|c|c|c|}
\hline Item & Statement & SD & D & $\mathbf{N}$ & A & SA \\
\hline \multirow[t]{2}{*}{ BT1 } & The e-wallet application has & 3 & 7 & 94 & 116 & 80 \\
\hline & $\begin{array}{l}\text { guaranteed the confidentiality of my } \\
\text { data. }\end{array}$ & $1.00 \%$ & $2.33 \%$ & $31.33 \%$ & $38.67 \%$ & $26.67 \%$ \\
\hline \multirow[t]{2}{*}{ BT2 } & The e-wallet application guarantees & 3 & 3 & 77 & 126 & 91 \\
\hline & $\begin{array}{l}\text { security in transactions and payment } \\
\text { processes made by me. }\end{array}$ & $1.00 \%$ & $1.00 \%$ & $25.67 \%$ & $42.00 \%$ & $30.33 \%$ \\
\hline \multirow[t]{2}{*}{ BT3 } & I believe transacting and making & 1 & 12 & 100 & 111 & 76 \\
\hline & $\begin{array}{l}\text { payments with an e-wallet poses no } \\
\text { risk. }\end{array}$ & $0.33 \%$ & $4.00 \%$ & $33.33 \%$ & $37.00 \%$ & $25.33 \%$ \\
\hline \multirow[t]{2}{*}{ BT4 } & I didn't find it difficult when using the & 1 & 2 & 70 & 133 & 94 \\
\hline & e-wallet application. & $0.33 \%$ & $0.67 \%$ & $23.33 \%$ & $44.33 \%$ & $31.33 \%$ \\
\hline \multirow[t]{4}{*}{ BT5 } & I didn't have any problems or & 2 & 10 & 63 & 138 & 87 \\
\hline & $\begin{array}{l}\text { problems when using the e-wallet } \\
\text { application. }\end{array}$ & $0.67 \%$ & $3.33 \%$ & $21.00 \%$ & $46.00 \%$ & $29.00 \%$ \\
\hline & Total Frequency & 10 & 34 & 404 & 624 & 428 \\
\hline & Percentage & $0.67 \%$ & $2.27 \%$ & $26.93 \%$ & $41.60 \%$ & $28.53 \%$ \\
\hline
\end{tabular}

Source: Data processed by the author (2021) 
348 | The Effect of Service Quality and Brand Image on Repurchase Intention With Brand Trust as Mediating Variable by The Generation Z of E-Wallet Consumers in Jakarta

Table 4. Descriptive Analysis Table Repurchase Intention

\begin{tabular}{|c|c|c|c|c|c|c|}
\hline Item & Statement & SD & D & $\mathbf{N}$ & A & SA \\
\hline \multirow[t]{2}{*}{$\mathbf{R I 1}$} & I have repeatedly transacted and & 2 & 5 & 58 & 120 & 115 \\
\hline & $\begin{array}{l}\text { made payments with the e-wallet } \\
\text { application. }\end{array}$ & $0.67 \%$ & $1.67 \%$ & $19.33 \%$ & $40.00 \%$ & $38.33 \%$ \\
\hline \multirow[t]{2}{*}{$\mathbf{R I 2}$} & The e-wallet application is the first & 2 & 7 & 65 & 130 & 96 \\
\hline & $\begin{array}{l}\text { choice when transacting or making } \\
\text { payments online. }\end{array}$ & $0.67 \%$ & $2.33 \%$ & $21.67 \%$ & $43.33 \%$ & $32.00 \%$ \\
\hline \multirow[t]{2}{*}{$\mathbf{R I 3}$} & I like transaction activities or & 2 & 4 & 58 & 142 & 94 \\
\hline & $\begin{array}{l}\text { payments through e-wallet } \\
\text { applications. }\end{array}$ & $0.67 \%$ & $1.33 \%$ & $19.33 \%$ & $47.33 \%$ & $31.33 \%$ \\
\hline \multirow[t]{2}{*}{$\mathbf{R I 4}$} & The e-wallet application is the best & 2 & 9 & 73 & 145 & 71 \\
\hline & $\begin{array}{l}\text { digital payment application } \\
\text { compared to other digital payment } \\
\text { applications. }\end{array}$ & $0.67 \%$ & $3.00 \%$ & $24.33 \%$ & $48.33 \%$ & $23.67 \%$ \\
\hline \multirow[t]{2}{*}{ RI5 } & I recommend using the e-wallet app & 2 & 6 & 75 & 133 & 84 \\
\hline & to others. & $0.67 \%$ & $2.00 \%$ & $25.00 \%$ & $44.33 \%$ & $28.00 \%$ \\
\hline \multirow[t]{2}{*}{ RI6 } & I rarely consider switching to a digital & 1 & 11 & 92 & 123 & 73 \\
\hline & $\begin{array}{l}\text { payment application other than an e- } \\
\text { wallet application. }\end{array}$ & $0.33 \%$ & $3.67 \%$ & $30.67 \%$ & $41.00 \%$ & $24.33 \%$ \\
\hline & Total Frequency & 11 & 42 & 421 & 793 & 533 \\
\hline & Percentage & $0.61 \%$ & $2.33 \%$ & $23.39 \%$ & $44.06 \%$ & $29.61 \%$ \\
\hline
\end{tabular}

Source: Data processed by the author (2021)

\section{Discussion}

In Table 1, the service quality variable (X1) has 5 indicators with answer options using a Likert scale 1-5 s beginning from 1 = Strongly Disagree, $2=$ Disagree, $3=$ Neutral, 4 = Agree, 5 = Strongly Agree. Contained in table 1 , the descriptive analysis of the Service Quality (X1) variable, that the option $S=$ Agree is the option most chosen by respondents compared to other options, namely 684 or $45.60 \%$ with the statement:

"Admin fees for each transaction paid on e-wallet applications is cheaper than other digital payment applications."
Furthermore, the second most chosen option from respondents is option four = Strongly Agree with 492 or $32.80 \%$ with the statement.

"The e-wallet application speeds up or improves my time efficiency when transacting financially online."

Thus, the option expressing disagreement has a lower total score than the agree option. So, it can conclude that respondents tend to answer positively to the Service Quality statement (X1).

In Table 2, the brand image variable (X2) has 5 indicators with answer options using a Likert scale 1-5 beginning from $1=$ Strongly Disagree, $2=$ Disagree, $3=$ Average, 4 = Agree, 5 = Strongly agree. 
Contained in table 1 , the descriptive analysis of the brand image variable (X2), that option $4=$ Agree is the option most chosen by respondents compared to other options, namely 709 or $47.27 \%$ with the statement:

"E-wallet companies have a good and credible reputation."

Furthermore, the second largest option from respondents was option five $=$ Strongly Agree with a total of 442 or 29.47\% with the statement:

"The e-wallet application has a distinctive logo so that it is easy for me to remember."

Thus, the option expressing disagreement has a much lower total value than the agree option. So, it can conclude that respondents tend to answer positively to brand image statements (X2).

In Table 3, the brand trust variable $(Y)$ has 5 indicators with answer options using a Likert type 1-5 beginning from $1=$ Strongly Disagree, $2=$ Disagree, $3=$ Average, $4=$ Agree, 5 = Strongly agree . Contained in table 3, the descriptive analysis of the brand trust variable $(\mathrm{Y})$ that option 4 = Agree is the option most chosen by respondents compared to other options, namely 624 or $41.60 \%$ with the statement:

"I do not get any problems or obstacles when using e-wallet application."
Furthermore, the second largest option from respondents was option five $=$ Strongly Agree with a total of 428 or $28.53 \%$ with the statement:

"I do not find any difficulties when using the e-wallet application."

Thus, the option expressing disagreement has a lower total score than the agree option. So, it can conclude that respondents tend to answer positively to brand trust statements $(Y)$.

In Table 4, the repurchase intention variable $(Y)$ has 6 indicators with answer options using a Likert scale 1-5 beginning from 1 = Strongly Disagree, 2 = Disagree, 3 = Average, 4 = Agree, $5=$ Strongly agree. Contained in table 4, descriptive analysis of the repurchase intention variable $(Z)$ that option 4 = Agree is the option most chosen by respondents compared to other options, namely 793 or $44.06 \%$ with the statement:

"E-wallet application is the best digital payment application so far. compared to other digital payment applications".

Furthermore, the second largest option from respondents is option five $=$ Strongly Agree with a total of 533 or $29.61 \%$ with the statement:

"I have repeatedly transacted and made payments with the e-wallet application."

Table 5. Validity Test Results

\begin{tabular}{l|c|cl}
\hline \multirow{2}{*}{ Variable } & $\begin{array}{c}\text { Cronbach's } \\
\text { Alpha }\end{array}$ & $\begin{array}{c}\text { N of } \\
\text { Items }\end{array}$ & Information \\
\cline { 2 - 3 } Service Quality $(\mathrm{X} 1)$ & 0,872 & 5 & Reliable \\
\hline Brand Image $(\mathrm{X} 2)$ & 0,885 & 5 & Reliable \\
\hline Brand Trust $(\mathrm{Y})$ & 0,900 & 5 & Reliable \\
\hline Repurchase Intention $(\mathrm{Z})$ & 0,876 & 6 & Reliable \\
\hline
\end{tabular}


$350 \mid$ The Effect of Service Quality and Brand Image on Repurchase Intention With Brand Trust as Mediating Variable by The Generation Z of E-Wallet Consumers in Jakarta

Source: Data processed by the author (2021)

Table 6. Reliability Test Results

\begin{tabular}{|c|c|c|c|c|}
\hline Variable & Indicators & r-values & r-table & Information \\
\hline \multirow{5}{*}{$\begin{array}{l}\text { Service Quality } \\
\text { (X1) }\end{array}$} & SQ1 & 0,830 & 0,113 & Valid \\
\hline & SQ2 & 0,789 & 0,113 & Valid \\
\hline & SQ3 & 0,792 & 0,113 & Valid \\
\hline & SQ4 & 0,841 & 0,113 & Valid \\
\hline & SQ5 & 0,817 & 0,113 & Valid \\
\hline \multirow{5}{*}{$\begin{array}{l}\text { Brand } \\
\text { Image } \\
(X 2)\end{array}$} & $\mathrm{BI} 1$ & 0,806 & 0,113 & Valid \\
\hline & $\mathrm{BI} 2$ & 0,819 & 0,113 & Valid \\
\hline & $\mathrm{BI3}$ & 0,853 & 0,113 & Valid \\
\hline & $\mathrm{B} 14$ & 0,841 & 0,113 & Valid \\
\hline & BI5 & 0,821 & 0,113 & Valid \\
\hline \multirow{5}{*}{$\begin{array}{l}\text { Brand Trust } \\
\text { (Y) }\end{array}$} & BT1 & 0,864 & 0,113 & Valid \\
\hline & BT2 & 0,857 & 0,113 & Valid \\
\hline & BT3 & 0,845 & 0,113 & Valid \\
\hline & BT4 & 0,816 & 0,113 & Valid \\
\hline & BT5 & 0,841 & 0,113 & Valid \\
\hline \multirow{6}{*}{$\begin{array}{l}\text { Repurchase } \\
\text { Intention } \\
\text { (Z) }\end{array}$} & RI1 & 0,765 & 0,113 & Valid \\
\hline & $\mathrm{RI} 2$ & 0,803 & 0,113 & Valid \\
\hline & $\mathrm{RI3}$ & 0,797 & 0,113 & Valid \\
\hline & $\mathrm{R} / 4$ & 0,789 & 0,113 & Valid \\
\hline & $\mathrm{RI5}$ & 0,782 & 0,113 & Valid \\
\hline & RI6 & 0,782 & 0,113 & Valid \\
\hline
\end{tabular}

Source: Data processed by the author (2021)

\section{Validity and Reliability Test}

In table 5 , the results of the respondent's answers will be processed by the researcher by considering the validity requirements, namely $r$ arithmetic $r$ table with a significance of $5 \%$, where the value of the $r$ table from 300 samples is 0.113 . Therefore, the results of the validity of each item/item must be greater than 0.113 . The method used in the validity test is Pearson Product Moment Correlation using SPSS version 25 software. Based on Table 5, the results for all indicators on the four research variables show that they have a calculated $r$-value greater than the $r$ table. From these results, it can state that all hands are valid.

In Table 6, the reliability test is performed with the Cronbach Alpha formula. If the reliability value is less than 0.6 , it can be said to be not very good, while 0.7 is acceptable, and 0.8 can be said to be good. According to Table 6 above, the Cronbach alpha coefficient value of the service quality variable (X1) with five indicators is 0.872 . The Cronbach alpha 
coefficient value of the brand image (X2) with five hands is 0.885 . The Cronbach alpha coefficient of brand trust $(Y)$ with five indicators is 0.900 . The Cronbach alpha coefficient value of repurchase intention ( $Z$ ) with six hands is 0.876 . The Cronbach $\alpha$ coefficient values of the four variables are all greater than 0.70 , so it can be concluded that the indicator measurement tools of the four research variables used are reliable and can be used for further analysis.

\section{Confirmatory Factor Analysis}

Table 7. Confirmatory Factor Analysis Service Quality

\begin{tabular}{cccc}
\hline $\begin{array}{c}\text { The } \\
\text { goodness } \\
\text { of Fit } \\
\text { Indices }\end{array}$ & $\begin{array}{c}\text { Cut- } \\
\text { off } \\
\text { Value }\end{array}$ & Result & $\begin{array}{c}\text { Model } \\
\text { Evaluation }\end{array}$ \\
\cline { 2 - 4 } CMIN/DF & $<3$ & 2,304 & Good Fit \\
\hline GFI & $\geq$ & 0,98 & Good Fit \\
& 0,90 & & \\
\hline SRMR & $<$ & 0,022 & Good Fit \\
& 0,05 & & \\
\hline RMSEA & $\leq$ & 0,066 & Good Fit \\
& 0,08 & & \\
\hline AGFI & $\geq$ & 0,95 & Good Fit \\
& 0,90 & & \\
\hline NNFI & $\geq$ & 0,99 & Good Fit \\
& 0,90 & & \\
\hline CFI & $\geq$ & 0,99 & Good Fit \\
& 0,90 & & \\
\hline
\end{tabular}

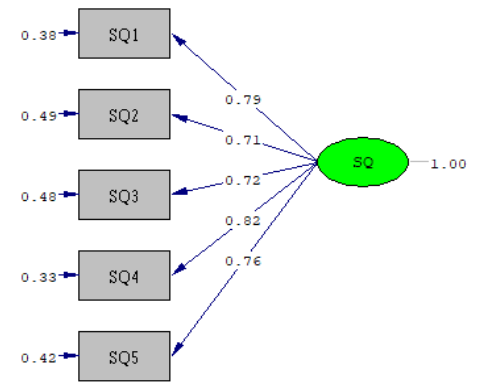

Chi-gquare $=11.52, d f=5$, P-value $=0.04203$, RMgEA $=0.066$

Figure 2. Model First Order Construct Variable Service Quality

In table 7 and figure 2, the results of the test service quality variable instrument (X1), which has five indicators. after processing the model on the firstorder construct shows results that there are no wasted indicators and produces a good level of acceptance with the effects of CMIN/DF 2.304; GFI 0.98; SRMR 0.022; RMSEA 0.066; AGFI 0.95; NNFI 0.99; CFI 0.99 . Thus, the model is good because the goodness of fit indices are in the excellent fit category, so there is no need to modify the model.

Table 8. Confirmatory Factor Analysis Brand Image

\begin{tabular}{cccc}
$\begin{array}{c}\text { The } \\
\text { goodnes } \\
\text { s of Fit } \\
\text { Indices }\end{array}$ & $\begin{array}{c}\text { Cut- } \\
\text { off } \\
\text { Value }\end{array}$ & $\begin{array}{c}\text { Resul } \\
\mathbf{t}\end{array}$ & $\begin{array}{l}\text { Model } \\
\text { Evaluatio } \\
\mathbf{n}\end{array}$ \\
\cline { 2 - 4 } CMIN/DF & $<3$ & 2,168 & Good Fit \\
\hline GFI & $\geq 0,90$ & 0,99 & Good Fit \\
\hline SRMR & $<0,05$ & 0,019 & Good Fit \\
\hline RMSEA & $\leq 0,08$ & 0,062 & Good Fit \\
\hline AGFI & $\geq 0,90$ & 0,96 & Good Fit \\
\hline NNFI & $\geq 0,90$ & 0,99 & Good Fit \\
\hline CFI & $\geq 0,90$ & 0,99 & Good Fit
\end{tabular}

Source: Data processed by the author (2021) 
352 The Effect of Service Quality and Brand Image on Repurchase Intention With Brand Trust as Mediating Variable by The Generation Z of E-Wallet Consumers in Jakarta

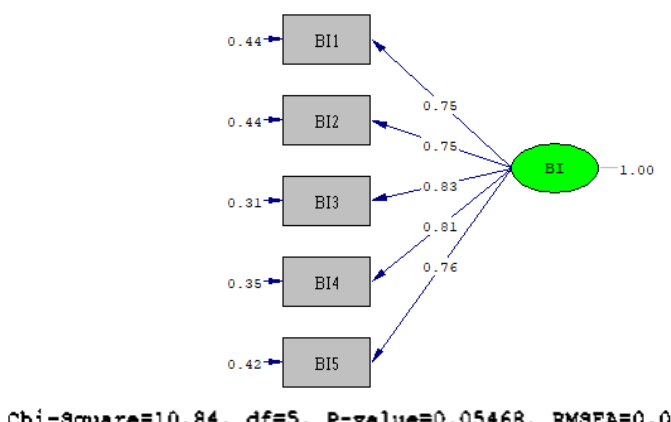

Figure 3. Model First Order Construct Variable Brand Image

In table 8 and figure 3 , the test results of the brand image variable instrument (X2), which has five indicators, then after processing the model on the first-order construct shows the results that there are no wasted indicators and produces a good level of acceptance with the effects of CMIN/DF 2,168; GFI 0.99; SRMR 0.019; RMSEA 0.062; AGFI 0.96; NNFI 0.99; CFI 0.99. Thus, the model is good because the goodness of fit indices are in the excellent fit category, so there is no need to modify the model.

Table 9. Confirmatory Factor Analysis Brand Trust

\begin{tabular}{cccc}
\hline $\begin{array}{c}\text { Goodness } \\
\text { of Fit } \\
\text { Indices }\end{array}$ & $\begin{array}{c}\text { Cut- } \\
\text { off } \\
\text { Value }\end{array}$ & Result & $\begin{array}{c}\text { Model } \\
\text { Evaluation }\end{array}$ \\
\hline CMIN/DF & $<3$ & 1,840 & Good Fit \\
\hline GFI & $\geq 0,90$ & 0,99 & Good Fit \\
\hline SRMR & $<0,05$ & 0,017 & Good Fit \\
\hline RMSEA & $\leq 0,08$ & 0,053 & Good Fit \\
\hline AGFI & $\geq 0,90$ & 0,96 & Good Fit \\
\hline NNFI & $\geq 0,90$ & 0,99 & Good Fit \\
\hline CFI & $\geq 0,90$ & 1,00 & Good Fit \\
\hline
\end{tabular}

Source: Data processed by the author (2021)

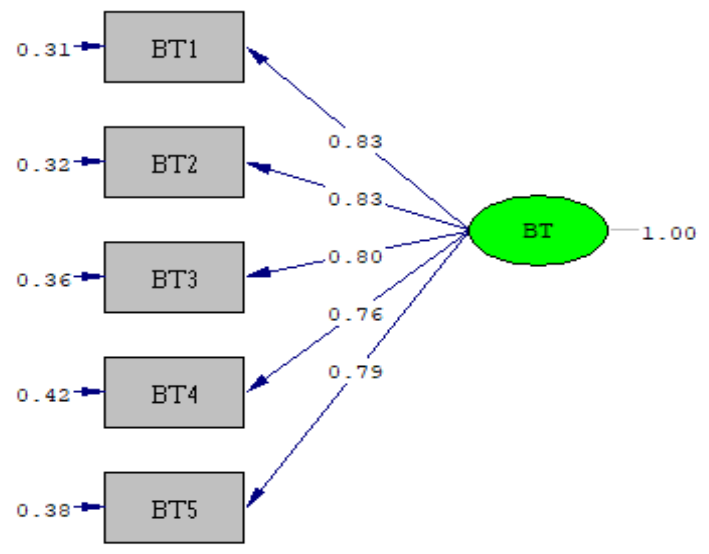

Chi-9quare=9.20, df=5, P-value=0.1011B, RMSEA=0.053

Figure 4. Model First Order Construct Variable Brand Trust

In table 9 and figure 4, the test results of the brand trust variable instrument $(\mathrm{Y})$, which has five indicators, then after processing the model on the first-order construct shows the results that there are no wasted indicators and produces a good level of acceptance with the effects of CMIN/DF 1,840; GFI 0.99; SRMR 0.017; RMSEA 0.053; AGFI 0.96; NNFI 0.99; CFI 1.00. Thus, the model is good because the goodness of fit indices are in the excellent fit category, so there is no need to modify the model.

Table 10. Confirmatory Factor Analysis Repurchase Intention

\begin{tabular}{cccc}
$\begin{array}{c}\text { Goodness } \\
\text { of Fit } \\
\text { Indices }\end{array}$ & $\begin{array}{c}\text { Cut- } \\
\text { off } \\
\text { Value }\end{array}$ & Result & $\begin{array}{c}\text { Model } \\
\text { Evaluation }\end{array}$ \\
\hline CMIN/DF & $<3$ & 2,313 & Good Fit \\
\hline GFI & $\geq 0,90$ & 0,98 & Good Fit \\
\hline SRMR & $<0,05$ & 0,027 & Good Fit \\
\hline RMSEA & $\leq 0,08$ & 0,066 & Good Fit \\
\hline AGFI & $\geq 0,90$ & 0,95 & Good Fit \\
\hline NNFI & $\geq 0,90$ & 0,98 & Good Fit \\
\hline CFI & $\geq 0,90$ & 0,99 & Good Fit
\end{tabular}

Source : Data proccesed by author (2021) 


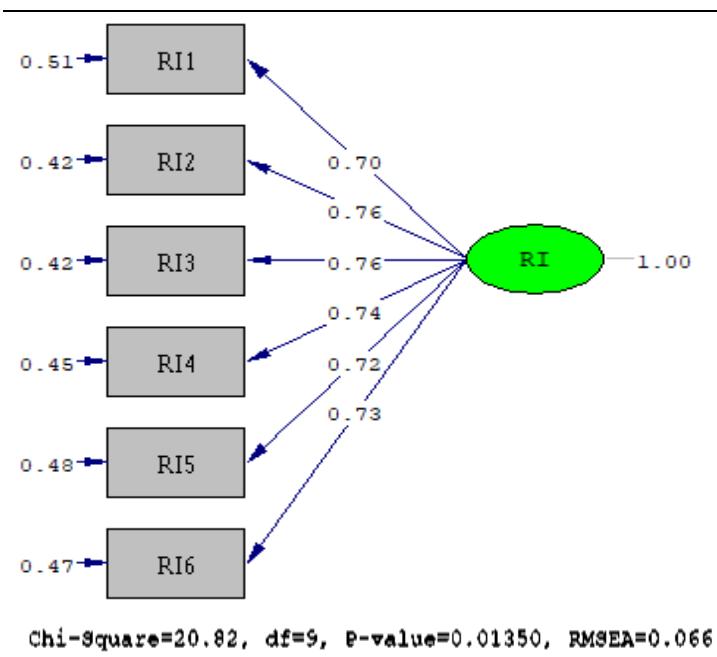

Figure 5. Model First Order Construct Variable Repurchase Intention

In table 10 and figure 5, the test results of the repurchase intention variable instrument (Z), which has six indicators, then after processing the model on the first-order construct shows the results that there are no wasted indicators and produces a good level of acceptance with the effects of CMIN/DF 2,313; GFI 0.98; SRMR 0.027; RMSEA 0.066; AGFI 0.95; NNFI 0.98; CFI 0.99. Thus, the model is good because the goodness of fit indices are in the excellent fit category, so there is no need to modify the model.

\section{Full Structural Equation Modelling (SEM)}

Table 11. Confirmatory Factor Analysis Full Model SEM

\begin{tabular}{|c|c|c|c|}
\hline $\begin{array}{l}\text { The } \\
\text { goodness } \\
\text { of Fit } \\
\text { Indices }\end{array}$ & $\begin{array}{l}\text { Cut- } \\
\text { off } \\
\text { Value }\end{array}$ & Result & $\begin{array}{l}\text { Model } \\
\text { Evaluation }\end{array}$ \\
\hline CMIN/DF & $<3$ & 1,641 & Good Fit \\
\hline GFI & $\geq 0,90$ & 0,91 & Good Fit \\
\hline SRMR & $<0,05$ & 0,035 & Good Fit \\
\hline RMSEA & $\leq 0,08$ & 0,046 & Good Fit \\
\hline
\end{tabular}

\begin{tabular}{cccc}
\hline AGFI & $\geq 0,90$ & 0,89 & Marginal Fit \\
\hline NNFI & $\geq 0,90$ & 0,99 & Good Fit \\
\hline CFI & $\geq 0,90$ & 0,99 & Good Fit
\end{tabular}

Source: Data processed by the author (2021)

The model is good because the RMSEA value is 0.046 or less than 0.08 . Also, most of the goodness of fit indices criteria are already in the excellent fit category, so there is no need to modify the model.

In Figure 6 below, the full SEM model in this research aims to analyze the connection between the four variables to see whether the independent variable can influence the dependent variable. The complete model should first be tested for goodness of fit, as was done for each variable in the previous figure. If the model does not reach the expected value, it is necessary to modify the indices according to the suggestion in the Lisrel software. From the data processing results, the whole model formed has met the requirements to be a good fit. 
354 | The Effect of Service Quality and Brand Image on Repurchase Intention With Brand Trust as Mediating Variable by The Generation Z of E-Wallet Consumers in Jakarta

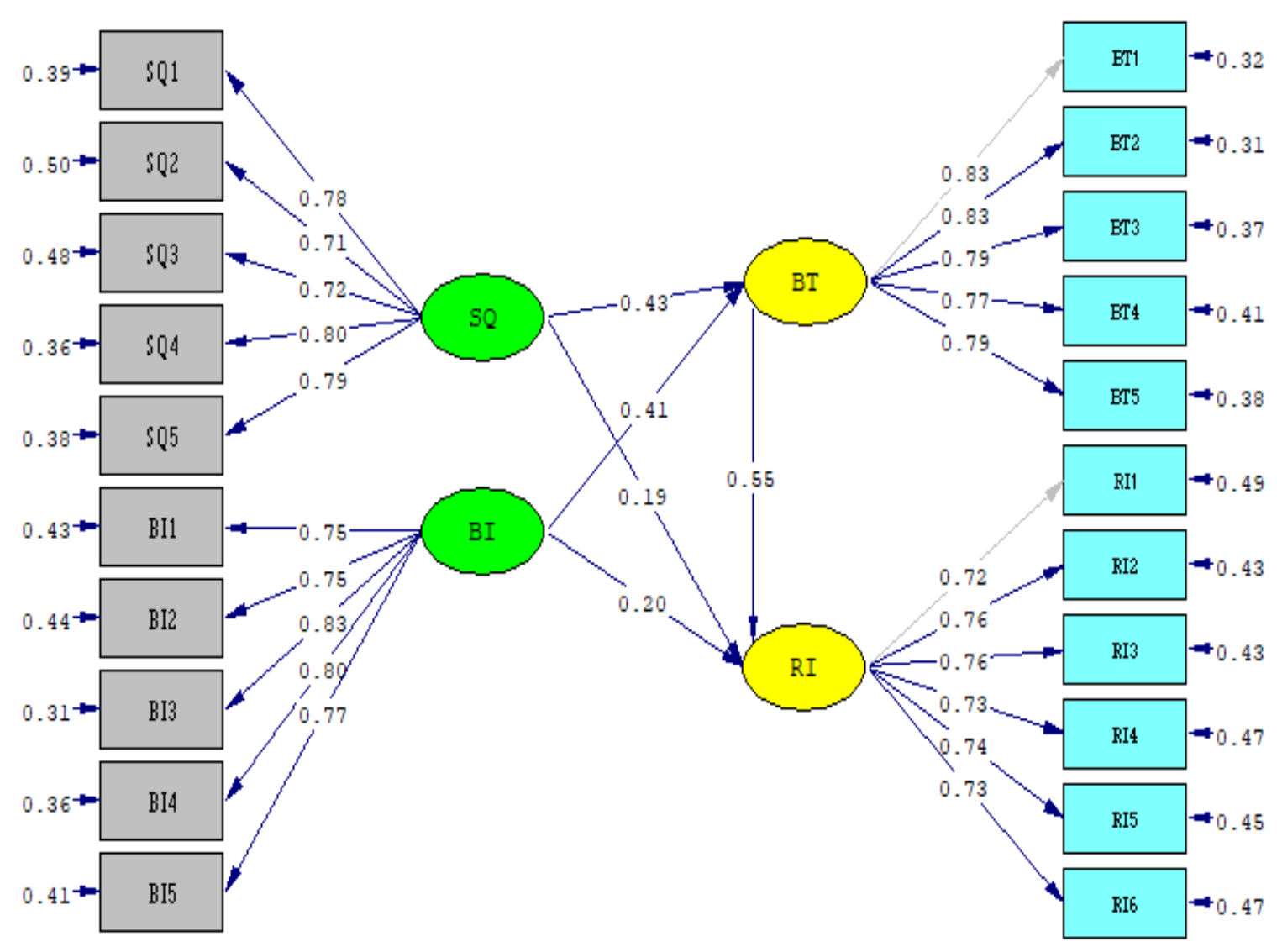

Chi-Square $=300.32, \mathrm{df}=183, \mathrm{P}-$ value $=0.00000, \mathrm{RMSEA}=0.046$

Figure 6. Structural Equation Model Results

Table 12. Result of Direct and Indirect Effect

\begin{tabular}{|c|c|c|c|c|}
\hline \multicolumn{2}{|l|}{$\begin{array}{c}\text { Dependent } \\
\text { Variable }\end{array}$} & $\begin{array}{c}\text { Independent } \\
\text { Variable }\end{array}$ & $\begin{array}{l}\text { Direct } \\
\text { Effect }\end{array}$ & $\begin{array}{l}\text { Indirect } \\
\text { Effect }\end{array}$ \\
\hline Brand Trust & $\leftarrow$ & Service Quality & 0,43 & \\
\hline Brand Trust & $\leftarrow$ & Brand Image & 0,41 & \\
\hline $\begin{array}{l}\text { Repurchase } \\
\text { Intention }\end{array}$ & $\leftarrow$ & Service Quality & 0,19 & 0,23 \\
\hline $\begin{array}{l}\text { Repurchase } \\
\text { Intention }\end{array}$ & $\leftarrow$ & Brand Image & 0,20 & 0,22 \\
\hline $\begin{array}{l}\text { Repurchase } \\
\text { Intention }\end{array}$ & $\leftarrow$ & Brand Trust & 0,55 & \\
\hline
\end{tabular}

Source: Data processed by the author (2021) 


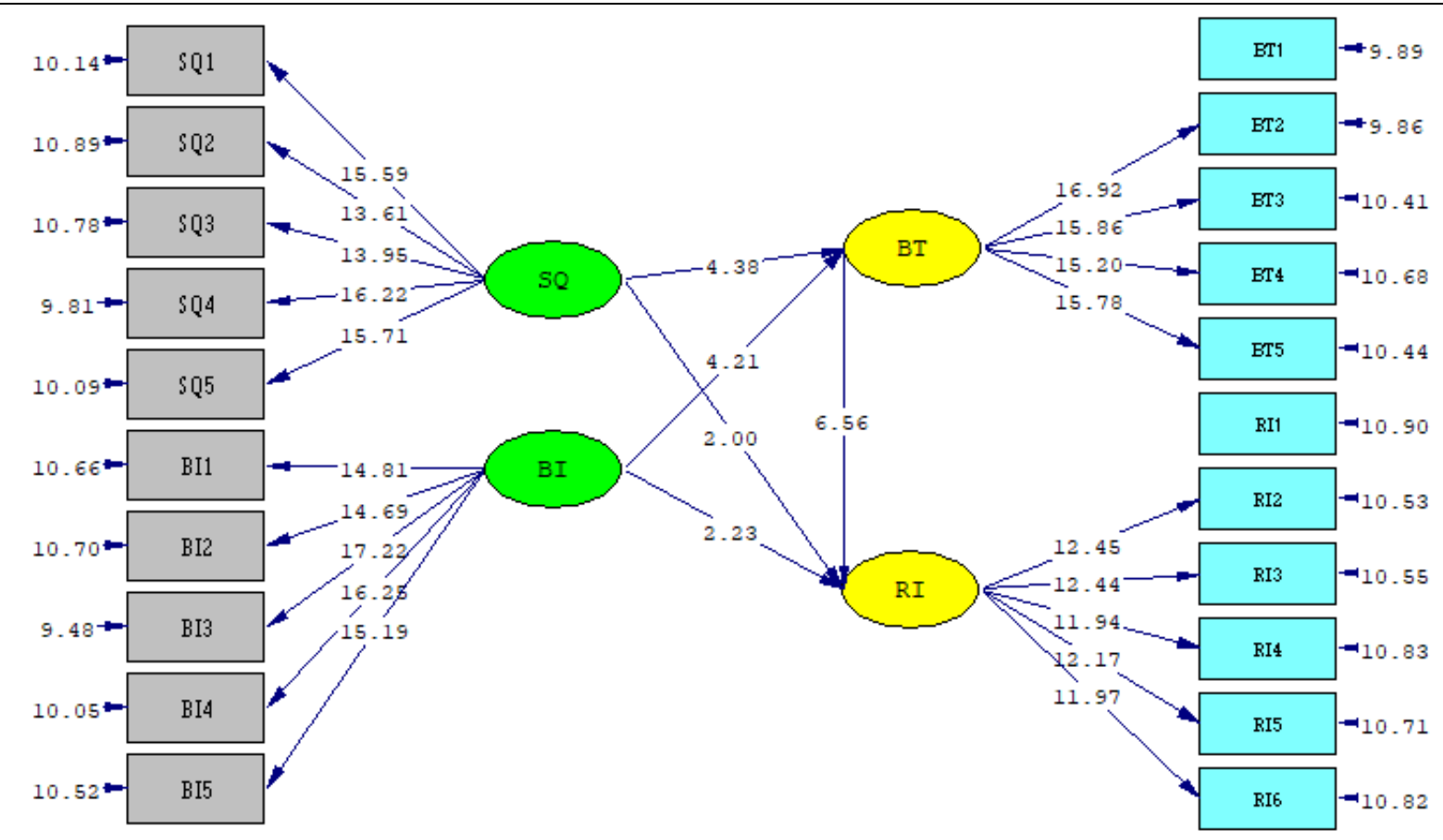

Chi-Square $=300.32, \mathrm{df}=183, \mathrm{P}-\mathrm{value}=0.00000, \mathrm{RMSEA}=0.046$

Figure 7. T-values SEM

Table 13. Hypothesis testing

\begin{tabular}{ccccc}
\hline Hypothesis & Path & $\begin{array}{c}\text { Path } \\
\text { Coefficient }\end{array}$ & $\begin{array}{c}\text { t } \\
\text { values }\end{array}$ & Interpretation \\
\hline $\mathrm{H} 1$ & $\mathrm{SQ} \rightarrow \mathrm{BT}$ & 0,43 & 4,38 & Significant \\
\hline $\mathrm{H} 2$ & $\mathrm{BI} \rightarrow \mathrm{BT}$ & 0,41 & 4,21 & Significant \\
\hline $\mathrm{H} 3$ & $\mathrm{BT} \rightarrow \mathrm{RI}$ & 0,55 & 6,56 & Significant \\
\hline $\mathrm{H} 4$ & $\mathrm{SQ} \rightarrow \mathrm{RI}$ & 0,19 & 2,00 & Significant \\
\hline $\mathrm{H} 5$ & $\mathrm{BI} \rightarrow \mathrm{RI}$ & 0,20 & 2,23 & Significant \\
\hline
\end{tabular}

Source: Data processed by the author (2021)

Table 14. Mediation Hypothesis Testing

\begin{tabular}{|ccccc|}
\hline Hypothesis & Path & $\begin{array}{c}\text { Indirect } \\
\text { Effect }\end{array}$ & $\begin{array}{c}\text { t } \\
\text { values }\end{array}$ & Interpretation \\
\hline $\mathrm{H} 6$ & $\mathrm{SQ} \rightarrow \mathrm{BT} \rightarrow \mathrm{RI}$ & 0,23 & 3,72 & Significant \\
\hline $\mathrm{H} 7$ & $\mathrm{BI} \rightarrow \mathrm{BT} \rightarrow \mathrm{RI}$ & 0,22 & 3,61 & Significant \\
\hline
\end{tabular}

Source: Data processed by the author (2021

Test for Direct and Indirect Effects 
356 | The Effect of Service Quality and Brand Image on Repurchase Intention With Brand Trust as Mediating Variable by The Generation Z of E-Wallet Consumers in Jakarta

Table 12 above shows the direct and indirect influence on the independent

variable to the dependent variable. It can see that the direct result of variable service quality $(\mathrm{X} 1)$ on brand trust $(\mathrm{Y})$ is 0.43 , and the direct influence of variable brand image $(\mathrm{X} 2)$ on brand trust $(\mathrm{Y})$ is 0.41 . The direct effect of brand trust $(\mathrm{Y})$ on repurchase intention $(Z)$ is 0.55 . The immediate impact of the service quality variable (X1) on repurchase intention $(Z)$ is 0.19 , and the indirect impact is 0.23 . This also occurs in the brand image variable (X2) on repurchase intention $(Z)$ with a direct effect of 0.20 and an indirect effect of 0.22 . This is because, in this research model, the variable brand trust $(\mathrm{Y})$ acts as an intervention between service quality (X1) and brand image (X2) on repurchase intention (Z).

\section{Hypothesis testing}

According to the structural equation model results performed in Table 13 and Table 14 above, seven hypotheses have been tested. In figure 7 , table 13 , and table 14 , If the $t$ value of the structural equation result is $>1.96$, there are significant effects between the variables, and the hypothesis is acceptable, and vice versa. If the $t$ value $<1.96$, the products between the variables are not significant or unacceptable. Where all relationships are declared to have a substantial effect because they have an atvalue $>1.96$, hypothesis testing was done by looking at the path coefficient value in the structural equation model in Figure 7 above.

Based on table 13 and table 14, it can see that the results of hypothesis testing are as follows:

1. Service quality variable (X1) on brand trust $(Y)$ has a path coefficient value of 0.43 and an at-value of $4.38>1.96$. The first hypothesis, which states that service quality (X1) significantly affects brand trust $(Y)$ in the e-wallet application, has substantial results. $\mathrm{H} 1$ can be accepted. These results are consistent with previous research conducted by Sultan \& Wong (2019), that service quality has a positive and significant impact on brand trust. Several previous studies also support this, such as research conducted by Najib \& Sosianika, (2019) and Al-dweeri et al., (2017).

2. Brand image variable (X2) on brand trust $(Y)$ has a path coefficient value of 0.41 and an at-value of $4.21>1.96$. These results are consistent with previous studies conducted by Han et al. (2019), which pointed out that the brand image significantly impacts Korean Airlines' brand trust. The second hypothesis, which states that brand image (X2) substantially affects brand trust $(Y)$ in the e-wallet application, has substantial results. $\mathrm{H} 2$ can be accepted. Several previous studies also support this, such as the study conducted by Kim et al., (2003) and Benhardy et al. (2020).

3. The brand trust variable $(Y)$ on repurchase intention ( $Z$ ) has a path coefficient value of 0.55 and an at-value of $6.56>1.96$. So the third hypothesis, which states that brand trust $(Y)$ has a significant effect on repurchase intention (Z) on e-wallet applications, has substantial results so that $\mathrm{H} 3$ can be accepted. This research is supported by 
the results found in the Horng, (2020) study, which states that brand trust in products will significantly affect repurchase intention for products traded on any website. In addition, the findings of Han et al. (2019) also found relationships and similar results, indicating that trust in the company's brand has a positive impact on the company's product or service repurchase intentions.

4. The service quality variable (X1) on repurchase intention ( $Z$ ) has a path coefficient value of 0.19 and an at-value of $2.00>1.96$. The fourth hypothesis, which states that service quality $(X 1)$ has a significant effect on repurchase intention (Z) on e-wallet applications, has substantial results, $\mathrm{H} 4$ can be accepted. These results prove similar results to previous studies by Lasmy et al. (2019), stating that service quality substantially impacts the repurchase intention of Grab and GoJek as online transportation. Several previous studies also support this, such as the study conducted by Chang et al. (2020) and Saleem et al. (2017)

5. The brand image variable (X2) on repurchase intention ( $Z$ ) has a path coefficient value of 0.20 and an at-value of $2.23>1.96$. So that the fifth hypothesis, namely brand image (X2), has a significant effect on repurchase intention ( $Z$ ) in e-wallet applications so that $\mathrm{H} 5$ can be accepted. The results found in this research are consistent with the study conducted by Saleem et al. (2017), who pointed out that brand image results are directly and significantly related to the repurchase intention of the Pakistan Airlines industry. Several previous studies also support this, such as the study conducted by Kotler et al. (2012).

6. The service quality variable $(X 1)$ is thought to affect repurchase intention (Z) through brand trust $(\mathrm{Y})$. This model has an indirect effects value of 0.23 and an at-value of $3.72>1.96$. So the sixth hypothesis, which states that service quality (X1) has a significant effect on repurchase intention $(Z)$ through brand trust $(Y)$ as an intervening in e-wallet applications, has substantial results so that $\mathrm{H} 6$ can be accepted. This is supported by research by Ahmad \& Zhang (2020), which states that brand trust significantly moderates the relationship between service quality with repurchase intention. The research results of Qi \& Yao, (2020) also found the intermediary relationship between brand trust in multi-channel integration service quality and repurchase intention and similar effects.

7. The brand image variable (X2) is thought to affect repurchase intention through brand trust $(Y)$. This model has an indirect effects value of 0.22 and an at-value of $3.61>1.96$. So the seventh hypothesis, which states that brand image (X2) has a significant effect on repurchase intention $(Z)$ through brand trust $(Y)$ as an intervening in e-wallet applications, has substantial results so that $\mathrm{H} 7$ can be accepted. The research results in this study are consistent with previous studies by Benhardy et al. (2020), which showed that brand trust actively regulates the relationship between brand image and repurchase 
358 | The Effect of Service Quality and Brand Image on Repurchase Intention With Brand Trust as Mediating Variable by The Generation Z of E-Wallet Consumers in Jakarta

intention.

\section{CONCLUSION}

In this research, the conclusion is an influence between service quality (X1) and brand image $(\mathrm{X} 2)$ on repurchase intention (Z) through brand trust ( $Y 1)$ as an intervening variable on generation $Z$ ewallet consumers in Jakarta. This study used 300 samples and produced seven hypotheses. There are several academic suggestions, namely that further research can use other variables in the use of ewallet applications, further analysis can be deepened and expanded by changing the object of study, adding samples, changing the characteristics of respondents with the aim of further research to obtain more diverse data and add the latest research references. There are several management suggestions, namely that companies can maintain admin fees on e-wallet applications which are cheaper than other digital payment applications, e-wallet companies can maintain and even increase the good and credible reputation that already exists in consumer perception, the absence of problems or obstacles when it must support consumers using e-wallet applications, prevented so that in the future there will not be any problems, or make solutions if there are problems that occur consumers so that consumer confidence in e-wallet applications can be maintained by e-wallet companies, customer satisfaction and pleasure It must be noted, customer expectations must be comparable and even exceed the services provided to increase repurchase intention.

\section{REFERENCES}

Ahmad, W., \& Zhang, Q. (2020). Green purchase intention: Effects of electronic service quality and customer green psychology. Journal of Cleaner Production, 267, 122053. https://doi.org/10.1016/j.jclepro.2020.1 $\underline{22053}$

Al-dweeri, R. M., Obeidat, Z. M., Al-dwiry, M. A., Alshurideh, M. T., \& Alhorani, A. M. (2017). The impact of e-service quality and e-loyalty on online shopping: moderating effect of esatisfaction and e-trust. International Journal of Marketing Studies, 9(2), 92103.

Al-Tit, A. A. (2015). The effect of service and food quality on customer satisfaction and hence customer retention. Asian Social Science, 11(23), 129.

APJII. (2021). Laporan Survei Internet APJII 2019-2020-Q2. APJII. https://www.apjii.or.id/content/read/39 /521/Laporan-Survei-Internet-APJII2019-2020-Q2

Banker, T. A. (2021). Indonesia e-wallet transaction to reach $\$ 18.5$ billion in 2021 amid fierce competition. The Asian Banker.

Benhardy, K. A., Hardiyansyah, Putranto, A., \& Ronadi, M. (2020). Brand image and price perceptions impact on purchase intentions: Mediating brand trust. Management Science Letters, 10(14), 3425-3432.

https://doi.org/10.5267/j.msl.2020.5.03 $\underline{5}$

Capgemini. (2021). World Payments Report 2021.

Capgemini. https://worldpaymentsreport.com/ 
Chang, W.-J., Liao, S.-H., Chung, Y.-C., \& Chen, H.-P. (2020). Service quality, experiential value and repurchase intention for medical cosmetology clinic: moderating effect of generation. Total Quality Management \& Business Excellence, 31(9-10), 1077-1097.

Hair, J. F., Anderson, R. E., Babin, B. J., \& Black, W. C. (2010). Multivariate data analysis: A global perspective (Vol. 7). Upper Saddle River, NJ: Pearson.

Han, H., Yu, J., Chua, B. L., Lee, S., \& Kim, W. (2019). Impact of core-product and service-encounter quality, attitude, image, trust and love on repurchase: Full-service vs. low-cost carriers in South Korea. International Journal of Contemporary Hospitality Management, 37(4), 1588-1608. https://doi.org/10.1108/IJCHM-05$\underline{2018-0376}$

Hardani, H. A., Ustiawaty, J., Istiqomah, R. R., Fardani, R. A., Sykmana, D. J., \& Auliya, N. H. (2020). Buku metode penelitian kualitatif \& kuantitatif. Yogyakarta: CV. Pustaka Ilmu Group.

Horng, S.-M. (2020). How Does Social Identification Moderate the Repurchase Intention?: From the Perspect of OGB. Journal of Organizational and End User Computing (JOEUC), 32(4), 1-25.

Iskandar, H., \& Berlianto, M. P. (2018). Analisis pengaruh brand image, perceived price, trust dan value terhadap behavioral intention pengguna smartphone Samsung Galaxy S8. Prosiding Seminar Nasional: Manajemen, Akuntansi, Dan Perbankan, 1(1), 33-49.

Išoraitè, M. (2018). Brand Image
Development. Eco forum, 7(1(14)).

Javed, M. K., \& Wu, M. (2020). Effects of online retailer after delivery services on repurchase intention: An empirical analysis of customers' experience and future confidence with the retailer. Journal of Retailing and Consumer Services, 54, 101942.

Juwariyah, S. (2021). Pengaruh Promotion Mix dan Brand Image terhadap Keputusan Pembelian pada Pondok Cokelat Hatta Samarinda. Jurnal Indonesia Sosial Sains, 2(9), 1606-1614.

Kaushal, S., \& Ghosh, A. (2016). Financial institutions and economic growth: An empirical analysis of Indian economy in the post liberalized era. International Journal of Economics and Financial Issues, 6(3).

Kemp, S. (2021). Digital 2021: The latest insights into the 'State of Digital.' We Are Social, Hootsuite. Pridobljeno s Https://Wearesocial. Com/Blog/2021/01/Digital-2021-theLatest insights-into-the-State-of-Digital.

Kim, D. J., Ferrin, D. L., \& Rao, H. R. (2003). Antecedents of consumer trust in B-to-C electronic commerce.

Kotler, P., Armstrong, G., Ang, S. H., Leong, S. M., Tan, C. T., \& Ho-Ming, O. (2012). Principles of marketing: an Asian perspective. Pearson/Prentice-Hall.

Kotler, P., Keller, K. L., Manceau, D., \& Dubois, B. (2016). Marketing Management, 15e édition. New Jersy: Pearson Education.

KPMG Siddharta Advisory. (2017). Retail Payments in Indonesia: Who Will Drive the Cashless Revolution? 
$360 \mid$ The Effect of Service Quality and Brand Image on Repurchase Intention With Brand Trust as Mediating Variable by The Generation Z of E-Wallet Consumers in Jakarta

Lasmy, Prabowo, H., Hamsal, M., \& Simatupang, B. (2019). E-Marketing and Service Quality on Repurchase Intention of Online Transportation. Proceedings of 2019 International Conference on Information Management and Technology, ICIMTech 2019, 1, 324-329. https://doi.org/10.1109/ICIMTech.2019. $\underline{8843759}$

Malhotra, N. K., \& Dash, S. (2010). An applied orientation. Marketing Research, 2.

Meola, A. (2017). Mobile fintech is here to stay with banking and payment services.

Najib, M. F., \& Sosianika, A. (2019). Retail service quality, satisfaction, and trust: the key to shopper loyalty in the context of the Indonesian traditional market. International Journal of Electronic Marketing and Retailing, 10(4), 425-440.

Pakurár, M., Haddad, H., Nagy, J., Popp, J., \& Oláh, J. (2019). The service quality dimensions that affect customer satisfaction in the Jordanian banking sector. Sustainability, 11(4), 1113.

Qalati, S. A., Vela, E. G., Li, W., Dakhan, S. A., Hong Thuy, T. T., \& Merani, S. H. (2021). Effects of perceived service quality, website quality, and reputation on purchase intention: The mediating and moderating roles of trust and perceived risk in online shopping. Cogent Business and Management, 8(1). https://doi.org/10.1080/23311975.202 $\underline{0.1869363}$

Qi, Y., \& Yao, Y. (2020). Influence of multichannel integration service quality on purchase intention of customers: dual mediating effect of brand experience and brand trust. Revista Argentina de Clínica Psicológica, 29(2), 58.

Saleem, M. A., Zahra, S., \& Yaseen, A. (2017). Impact of service quality and trust on repurchase intentions - the case of Pakistan airline industry. Asia Pacific Journal of Marketing and Logistics, 29(5), 1136-1159.

https://doi.org/10.1108/APJML-102016-0192

Srivastava, K., \& Sharma, N. K. (2013). Service quality, corporate brand image, and switching behavior: The mediating role of customer satisfaction and repurchase intention. Services Marketing Quarterly, 34(4), 274-291.

Sullivan, Y. W., \& Kim, D. J. (2018). Assessing the effects of consumers' product evaluations and trust on repurchase intention in e-commerce environments. International Journal of Information Management, 39, 199-219.

Sultan, P., \& Wong, H. Y. (2019). How service quality affects university brand performance, university brand image and behavioural intention: the mediating effects of satisfaction and trust and moderating roles of gender and study mode. Journal of Brand Management, 26(3), 332-347. https://doi.org/10.1057/s41262-018$\underline{0131-3}$

Tandon, U., Kiran, R., \& Sah, A. N. (2017). Customer Satisfaction as mediator between website service quality and repurchase intention: An emerging economy case. Service Science, 9(2), 106-120.

https://doi.org/10.1287/serv.2016.0159

Trivedi, S. K., \& Yadav, M. (2020). 
Repurchase intentions in $\mathrm{Y}$ generation: mediation of trust and e-satisfaction. Marketing Intelligence and Planning, 38(4), 401-415. https://doi.org/10.1108/MIP-02-2019$\underline{0072}$

Zhang, Y. (2015). The Impact of Brand Image on Consumer Behavior: A Literature Review. Open Journal of Business and Management, 03(01), 5862.

https://doi.org/10.4236/ojbm.2015.310 $\underline{06}$ for possible open access publication under the terms and conditions of the Creative Commons Attribution (CC BY SA) license (https://creativecommons.org/licenses/by-sa/4.0/). 